\title{
The Structure and Origin of the Cycadaceae.
}

\author{
BY \\ W. C. WORSDELL. \\ With seventeen Figures in the Text.
} O family of plants is exciting more interest at the present day than
the Cycadaceae, and this for the prime reason that they represent one of those forms of plant-life which link the types of the far past with those of the present modern world. They are placed to-day at the lowest level of the great Gymnosperm-class, but they possess certain peculiarities of habit, external morphology, and anatomical structure which undoubtedly suggest an affinity between them and that large group of the Vascular Cryptogams, the Ferns. The majority of authors who have written on the subject are at one on this broad question of Filicinean relationship. They begin to differ from one another, however, when considering more in detail the group or groups of Fern-like plants to which our modern Cycads are related or from which they have been derived, and also the lines along which the descent with modification has apparently taken place.

The group of Fern-like plants from which our modern Cycads are probably derived is that termed by Potonie the Cycadofilices, but more recently named by Scott and Oliver, Pteridospermeae, itself probably representing a transitional stage of evolution between the Ferns proper and modern Cycads.

Having been asked to contribute a résumé of my views as to the origin of Cycads from the Pteridosperms (views which have been founded chiefly on facts of their vascular anatomy), the following account is written in compliance with that request.

\section{The Habit and Structure of Cycads.}

I will first give a brief description of the characters of the Cycadaceae.

The Tree-fern-like habit of these plants is the first thing to be remarked; the thick stem often coated externally with an armour-plate of old leaf-bases, bears at its summit a crown of large fronds; but here

[Annals of Botany, Vo1. XX. No. LXXVIII. April, 1906.] 
the resemblance in habit to a Fern ceases, unless it be in the Fern-like foliage of the genera Stangeria and Bowenia. The male and female reproductive organs are borne on cones, each such cone being developed as a direct continuation of the main axis ; the growth in length of the plant is subsequently continued by means of a lateral vegetative shoot immediately below the cone, this latter being pushed to one side. The main mode of branching of the plant is thus sympodial. But monopodial branching also occurs where, as is quite frequently the case, short, lateral shoots are developed at intervals on the main axis. The plants are dioecious. In the case of the female plant of Cycas there is no cone developed, the seed-bearing sporophylls arising in groups at intervals directly on the main axis, this latter persisting in growth and developing time after time foliageleaves above the zone of sporophylls. This is probably a primitive ancestral condition, the cone-formation representing a phylogenetically younger character.

In all Cycads whorls of foliage- and scale-leaves are formed alternately on the vegetative stem.

It would appear that the tap-root of the plant early dies away, its place being taken by adventitious roots which arise from the stem-tissues. This also is a Fern-like character.

All Cycads are xerophytes, i.e. are adapted to withstand the conditions of drought and intense solar heat and light under which they grow; hence the armour-plate of thick leaf-bases on the stem, and the rigidity of structure and thick cuticularization of the leaves.

Let us turn now to the anatomical structure of the vegetative stem. The tissues are extremely parenchymatous and contain an abundance of starch. Mucilage-canals traverse both the wide pith and the cortex, passing also through the medullary rays of the vascular cylinder. They are continuous into the leaf, but not, as a rule, into the root. Periderm is present in the leaf-bases and outer cortex.

Of the nine genera of Cycads, four, viz. Cycas, Encephalartos, Macrozamia, and Bowenia, possess more than one vascular ring. In Cycas there may be as many as a dozen rings arranged concentrically one within the other. In any case, only the innermost of these rings arises in the first place as primary tissue with secondary cambial formations subsequently increasing its radial thickness. All the other vascular rings are entirely of secondary origin, being formed by the agency of a cambium. The remaining ${ }^{1}$ genera, viz. Stangeria, Zamia, Ceratozamia, and Dioon possess but a single ring in their stems. Both the xylem and phloem of each are extremely parenchymatous, being largely composed of very numerous medullary rays. This vascular tissue belongs to the collateral type of structure. The leaf-trace bundles, as they enter the stem to the number

1 But Microcycas has never yet been examined. 
of two from each leaf, are peculiar from the fact that they describe a girdlelike course part way around the stem, gradually passing inwards to join the central cylinder, having to traverse the medullary rays in order to reach the latter in those cases where two or more cylinders occur. Sometimes, however, as in Macrozamia, the leaf-traces pass directly inwards.

In all species of the genus Encephalartos, and in certain species only of Macrozamia there occurs a system of medullary bundles scattered in great numbers throughout the pith. Each is always accompanied on the side of the phloem by a mucilage-canal. These bundles are orientated in every conceivable direction as seen in a transverse section, and are collateral in structure. They are cauline in origin, uniting at various points with the primary vascular cylinder, but having no connexion with the leaf-traces.

The roots, both primary and adventitious, vary as regards the number of bundles or rays composing the stele; often the root is pent- or tetrarch at the base, i. e. near the cotyledonary node, becoming successively triand diarch as one proceeds towards the apex, but it is often diarch close to the node. A peculiar feature of Cycads is the possession of an apogeotropic root-system; each root branches in a dichotomous coralloid manner above the surface of the soil, and contains in the intercellular spaces of a particular zone of the cortex colonies of Anaboena, an Alga belonging to the Cyanophyceae.

The leaf, in most genera, is pinnately branched. But in Bowenia, Macrozamia heteromera, and Cycas Micholitzii it is further subdivided. This gives to them a more graceful Fern-like character. This Fern-like character is exhibited by Stangeria in another way. Each pinna of the frond possesses a thick midrib containing two or three vascular bundles; the rest of the broad lamina is supplied by dichotomouslybranching lateral veins running out to the margin. In Cycas the narrow pinna has also a midrib containing a single large bundle, but in this case there are no other bundles in the lamina. The vascular structure of the pinna here is particularly interesting. The bundle of the midrib is of collateral structure with a somewhat arched contour; the xylem is of the mesarch type, i. e. the protoxylem is situated in a more or less central position with, towards the dorsal or phloem side, a little secondary centrifugal, and towards the ventral side a well-developed primary centripetal xylem. Transfusion-tissue, consisting of isodiametric tracheides whose function is to supply with water the mesophyll of the leaf, are situated on either side of the xylem, as seen in transverse section. They really constitute part of the centripetal xylem with which they are connected by elements transitional, not only in space, but also as regards the shape and other characters of the tracheides. The structure of the bundle just described is common to the bundles of the lamina in all genera of Cycads. In Cycas the inadequate functions of the transfusion-tissue are 
reinforced by an 'accessory transfusion-tissue,' consisting of the central elongated cells of the mesophyll which have become transformed into tracheides, and which extend from the ordinary transfusion-tissue to the margin of the leaf.

In all genera except Cycas and Stangeria a number of equal, parallel bundles traverses the lamina.

The vascular bundles of the petiole of the leaf are typically arranged in the form of an $\Omega$ as seen in transverse section, with the xylems directed inwards or towards the ventral surface of the leaf. There are, however, various complex modifications of this arrangement of which the extreme case is attained in Encephalartos, in whose petiole the bundles are extremely numerous, and are orientated in every conceivable direction. The petiolar bundles of Cycads possess the same mesarch structure as those of the lamina, but the centripetal xylem is very great in amount, and is thus strongly contrasted with the very small development of the primary centrifugal xylem.

As regards the vascular anatomy of the cone, the general feature is the possession of a single cylinder of separate bundles, each bundle being collateral in structure with a large amount of secondary superadded to the primary tissue. In certain genera (Stangeria, Bowenia, Ceratozamia) the endarch structure of the bundles at the very base of the peduncle is superseded throughout the rest of the length of that organ by the mesarch character, owing to the presence of scattered primary centripetal tracheides, to which is sometimes attached a protoxylem-group distinct from that of the centrifugal part of the xylem.

The sporophylls are spirally arranged on the cone and are short, highlymodified structures, each with a very thick shield-like terminal portion and a narrow stalk. The very numerous male sporangia are scattered in sori over the lower surface of the sporophyll; the female sporangia are two in number, seated likewise on the lower surface of the organ, but on the adaxial side of the peltate portion. Two bundles supply each sporophyll as a rule; these branch so as to form a transverse row of strands. The bundles of the sporophyll which are situated below the level of insertion of the sporangia are characterized by the large amount of centrifugal, as compared with the centripetal, xylem which they possess as a result of their sporangium-supplying function. In the peltate portion of the sporophyll these relations are reversed.

Owing to the fact that they are not compactly grouped together in a cone but are borne loosely on the vegetative axis of the plant the female sporophylls or carpels of Cycas are more or less leaf-like in character, and possess rudimentary pinnae in their upper sterile portion. The ovules are usually about six in number (Cycas Normanbyana has two), and are borne on the sporophyll in the lateral position of pinnae. 
The ovule consists of the following parts : an outer fleshy, often brightlycoloured envelope which is intimately fused with a thick woody shell internal to it, within which again is another soft-celled tissue. The vascular bundles supplying the ovule are divided into two distinct systems: an outer one traversing the external fleshy envelope, and an inner supplying the internal soft tissue.

These, from the purely descriptive point of view, are the main facts of the structure of modern Cycads.

I will now see what we know as to the structure of the Medulloseae, a group of the Pteridosperms of which specimens have been obtained from the Coal Measures and the Permian. We know little as to the habit of these plants, but some of the stems found are of considerable thickness and length.

The vascular anatomy of the stem is of great interest, presenting a structure which combines the characters of that of Ferns and modern Cycads, for it exhibits on the one hand polystely and on the other welldeveloped secondary tissue in each stele.

If we take a species, viz. Medullosa Solmsii, which is one of the most Fern-like in its structure, we find, in a transverse section of the stem, a double ring of concentric bundles or steles surrounding a wide pith and surrounded in their turn by a wide cortex. The steles of the inner ring are somewhat smaller than those of the outer. Each individual stele in both rings consists of a central pith, in which primary tracheides are scattered, surrounded by a considerable development of secondary xylem and phloem. Small, concentric leaf-trace bundles occur just outside the outer ring of steles. In the pith are scattered very numerous, minute, concentric bundles, each largely formed of secondary tissue.

In $M$. anglica, Scott, there are only three steles of irregular shape and large size, each possessing a structure identical with that just described. Here and there, immediately outside the steles, is seen a much smaller, isolated, concentric strand termed by Scott 'anomalous' in the sense of representing something extra to the main group of large steles.

The leaf-trace bundles, immediately on leaving the steles, are perfectly concentric in structure, but very soon break up into a small group of collateral bundles, which still further subdivide on entering the leaf.

The stem of $M$. porosa, Cotta, belongs to the type in which the cylinder (at any rate frequently) is composed of a continuous band or zone of vascular tissue, which possesses in itself precisely the structure of one of the concentric steles of $M$. anglica, Scott, or $M$. Solmsii, Schenk. In this species the mutually-inverted parts of the secondary xylem and phloem are respectively equal in development. Numerous medullary bundles, of very much larger size than those of $M$. Solmsii, Schenk, occur, scattered irregularly through the pith; many of them are imperfectly concentric in structure. 
$M$. stellata, Cotta, var. typica, exhibits also in the region between the places of insertion of the leaf-trace bundles a continuous zone in transverse section, but here the inner xylem and phloem are very poorly developed as compared with the outer.

M. stellata, Cotta, var. gigantea, shows the same character. But here there occur in addition two or three extra cylinders from which all traces of the inner xylem and phloem (which may or may not have existed in the ancestor of the plant) are completely absent, so that these zones possess a collateral structure. They appear also to be entirely secondary in origin, for there are no signs of primary tracheides.

In $M$. Leuckarti, Göpp. and Stenz., there is a main cylinder composed of two or three very irregular, sinuous, elongated steles of considerable development; within this is a minor cylinder of similarly-shaped, but smaller steles, which abstricts off at places the smaller steles which compose the medullary system.

In $M$. porosa, Cotta, and $M$. Solmsii, Schenk, there is likewise an inner minor cylinder, but composed, in the first-named species, as also in $M$. Solmsii, Schenk, vars. incrassata and lignosa, of steles greatly reduced in size as compared with the main cylinder, forming in this respect a transition to the medullary steles lying irregularly scattered in the centre. They exhibit, moreover, the peculiarity of having the secondary xylem and phloem developed on the inner side only, and are therefore collateral in structure.

The foliage now known to have been borne by Medullosean-stems was that known as Alethopteris and Neuropteris ${ }^{1}$, the characters of which are very Fern-like.

The petioles of these fronds, known as Myeloxylon, possess, as seen in transverse section, an outer cortical region exhibiting the 'Dictyoxylon' sclerotic tissue; the rest of the organ contains large numbers of collateral, usually exarch bundles, orientated in every conceivable direction.

We will now describe the main features of the anatomy of another type of the Pteridosperms, viz. Lyginodendron. A transverse section of the stem of $L$. Oldhamium reveals the following structure: an outer 'Dictyoxylon' cortex; an inner soft-celled cortex; a periderm, probably arising from the pericycle; a central cylinder composed (frequently) of a number of more or less distinct and separate bundles each of which possesses the following structure : a mesarch primary xylem-strand, consisting of a central protoxylem with, on the inner side, a well-developed centripetal, and, on the outer side, a small amount of centrifugal xylem; attached to the outer side of each such primary strand is a thick fan-shaped mass of secondary xylem, bounded on its external side by a very much less-developed zone of phloem. Opposite each gap between the bundles a single large leaf-trace,

\footnotetext{
1 Probably also other types, such as Odontopteris and Linopteris, belonged to them.
} 
possessing a thick arc-shaped mass of secondary xylem, passes off; it soon divides into a pair of strands within the pericycle: these lose their secondary tissues, and, on passing into the leaf, again fuse into a single strand. Certain abnormal structures in the cylinder were also observed. Occasionally a cambium (which, in some cases, may form a continuous arc stretching from the normal cambium of one side of the bundle, round the inner side of the centripetal xylem, and joining the normal cambium of the opposite side) arises on the inner (ventral) side of the primary strand, there forming xylem and phloem with inverted orientation. Sometimes this abnormal cambium forms parenchymatous tissue only.

The foliage borne by Lyginodendron-stems was that termed, before its real relationships were established, Sphenopteris Hoeninghausii; it was very Fern-like, with finely subdivided segments. The petioles bearing these laminae bore the name of Rachiopteris aspera. A transverse section of this latter revealed a single large bundle of mesarch structure, with three or more protoxylem-groups situated near the periphery of the xylem; the whole was completely surrounded by phloem. The outer part of the cortex exhibited a Dictyoxylon-structure.

In Heterangium there is a single large solid stele in the stem, the structure of which is precisely that of one of the separate steles of the stem of Medullosa anglica, \&c., but the whole is on a larger scale. The characters of the cortex, leaf-traces, and petiolar bundles are similar to those in Lyginodendron. The foliage belonging to the stem is that known as Sphenopteris elegans.

\section{The Origin of Cycadean Structures.}

\section{Origin of Axial Structures.}

Most botanists are agreed that modern Cycads had their origin somewhere in the plexus of the Carboniferous or Permian Pteridosperms (Cycadofilices). If this is the case some indication of that origin should be discovered in the anatomical structure of the caulome or shoot. But opinion is divided as to which of the Pteridospermic types of stem-structure that of modern Cycads has been derived from. There is, on the one hand, the view which regards the central cylinder of the Cycad as derived from that of Lyginodendron or Heterangium, while the 'extrafascicular' cylinders of certain Cycads are held to be peculiar to them and of no ulterior phylogenetic importance or value. On the other hand, there is the view which regards the Cycadean cylinder as derived from that of such a form as Medullosa porosa. This latter is the view I shall adopt in this paper.

Now, in the first place, I will start out with the primary proposition that if ancestral characters are present at all in the vascular tissue they must be 


\section{I36 Worsdell.-The Structure and Origin of the Cycadaceae.}

sought for in two principal regions, viz. (I) in the cotyledonary or primary node, i.e. the approximately transitional region between root and stem; for it is here that the earliest tissues of the vascular system arise, and we know that it is in these tissues, developed earliest in the ontogeny, that ancestral traits are most likely to be found and recognized; (2) the flowering axis, for in this region the vascular tissue will have undergone less modification, than is the case with the vegetative stem, in the direction of subserving the
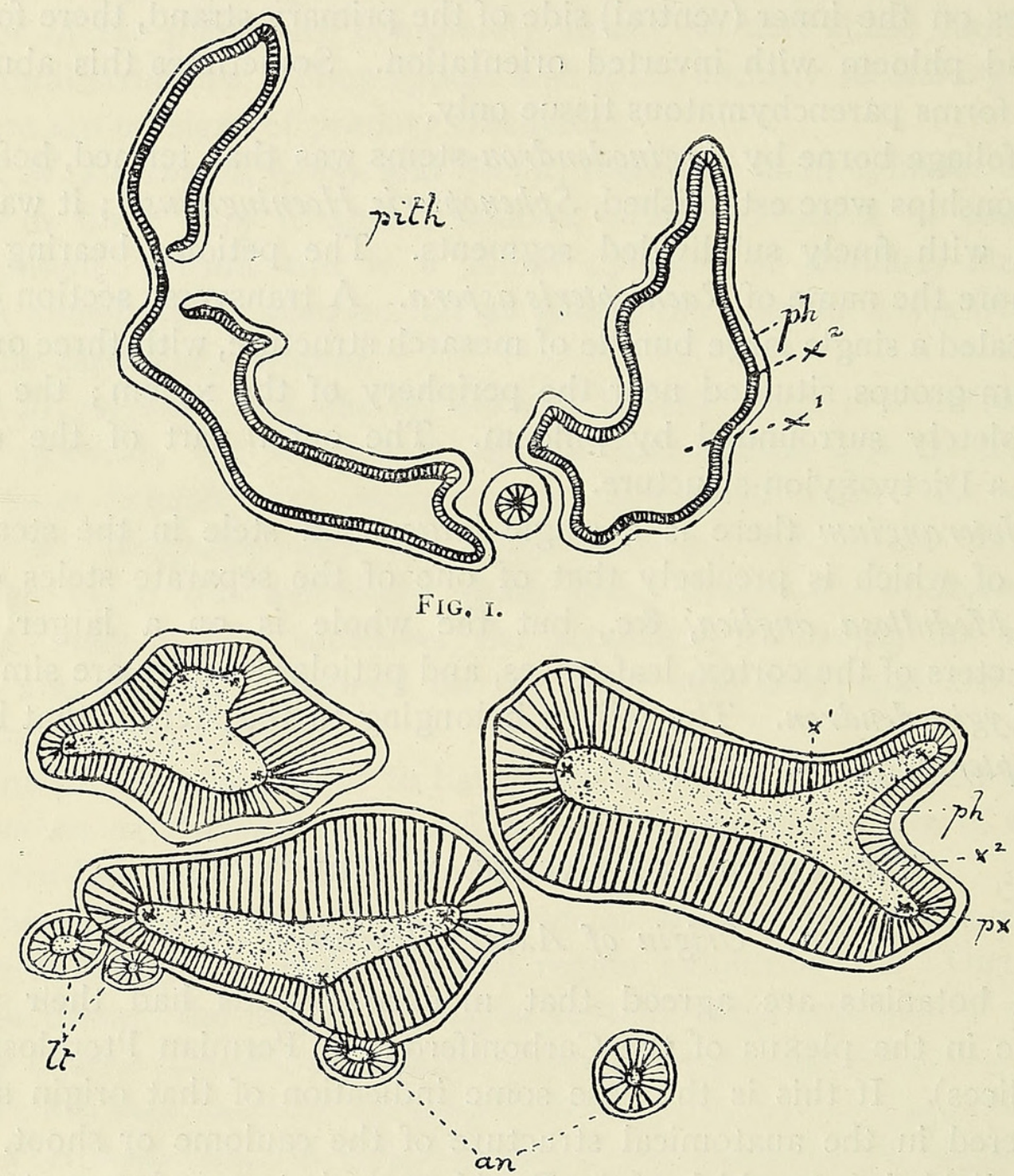

FIG. I $a$.

FIG. I. Encephalartos Barteri: diagrammatic transverse section of the seedling-axis in the region of the cotyledonary node, showing the medullosa-like steles (after Matte). FIG. I $a$. Medullosa anglica: diagrammatic transverse sections of vascular system of stem, showing three main steles, two accessory steles, and two leaf-traces (after Scott): $p h=$ phloem; $p x=$ protoxylem; $x^{1}=$ central primary xylem; $x^{2}=$ secondary xylem.

exigencies of conduction, and hence ancient characters which may be present will tend to be less obscured by the later adaptive accretions to the structure.

If, then, we examine the cotyledonary node of the stem of certain Cycads we find structural phenomena which, in my opinion, shed great light on the origin of the vascular tissue of the axis as a whole. 
Matte found in this region of the stem of a seedling of Encephalartos Barteri (as viewed in transverse section), instead of the usual continuous cylinder of endarch structure, three practically independent, distinct steles, each of very sinuous, irregular contour, and not forming a definite cylinder (Fig. I). This is, to my mind, the most important recent discovery in the structure of Cycads. Its significance, for my point of view, is immense. For this structure is clearly exactly comparable to that of such a type as Medullosa anglica, Scott (Fig. I a), above described ${ }^{1}$. It is an ancestral character, found here, and here only, in the very region we should most expect it, and soon lost as, passing upwards, the steles unroll and gradually

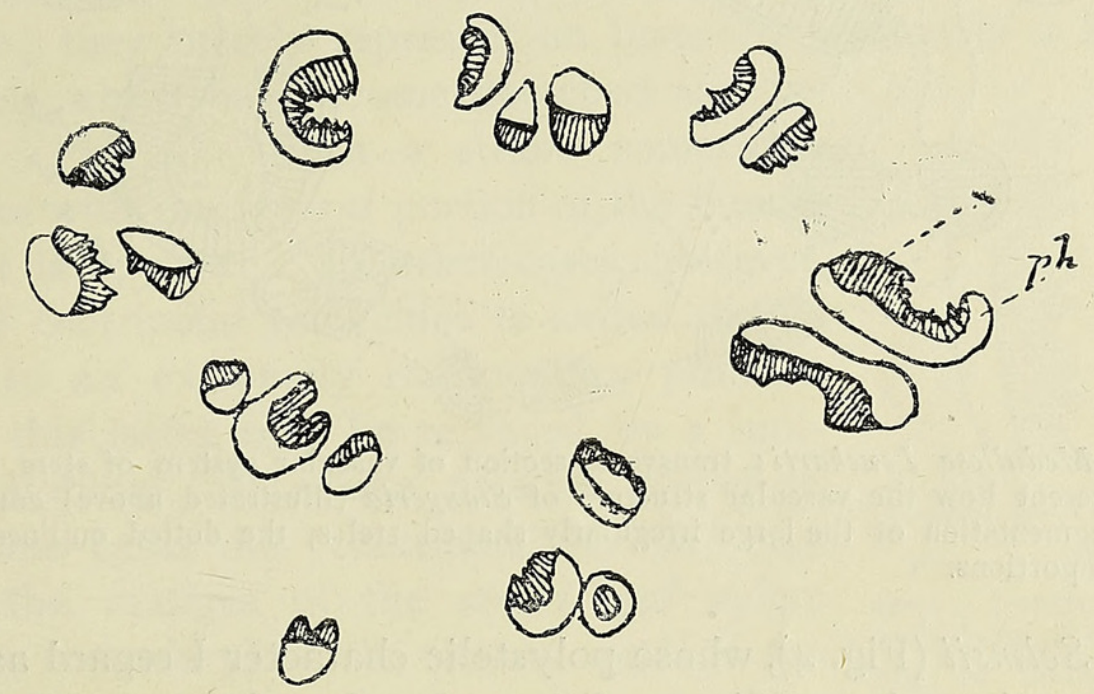

Fig. 2. Stangeria paradoxa: transverse section of lower (not lowest) region of vascular ring of peduncle of cone showing irregular orientation of the bundles (diagrammatic and reversed) (after Scott).

constitute the typical cylinder. This is the only instance of the kind hitherto observed in the vegetative stem.

In the structure of the peduncle of Stangeria, however, there is, in my opinion, further evidence available that the central cylinder is in reality composed of the one-sided remnants of a number of steles. In the lowest part of the peduncle there is nothing exceptional to be seen; but somewhat higher up, i.e. sufficiently so for the organ to exhibit its distinctive character, uninfluenced by the region of its origin lower down, the component bundles of the cylinder become orientated in a very irregular way: some lying back to back, with their long axes directed towards the centre of the organ, and at the same time more or less incurved at the ends, while others are horse-shoe-shaped; and one is completely concentric, with central protoxylem (Fig. 2). This peculiar structure can be readily explained if we suppose that the whole cylinder has been derived by

1 Dr. Matte informs me that there was no trace of any injury to the tissues in this region of the seedling-axis. He observed this structure in a single individual only; other seedlings did not possess it. He has since kindly enabled me to examine the sections for myself. 
fragmentation of a few (two or three) steles of extremely sinuous contour, such as are found in the stem of Medullosa Leuckarti, Göpp. and Stenz. (Fig. 3). If all the bundles, instead of only one or two, resulting from this fragmentation had remained concentric, we should have a structure like

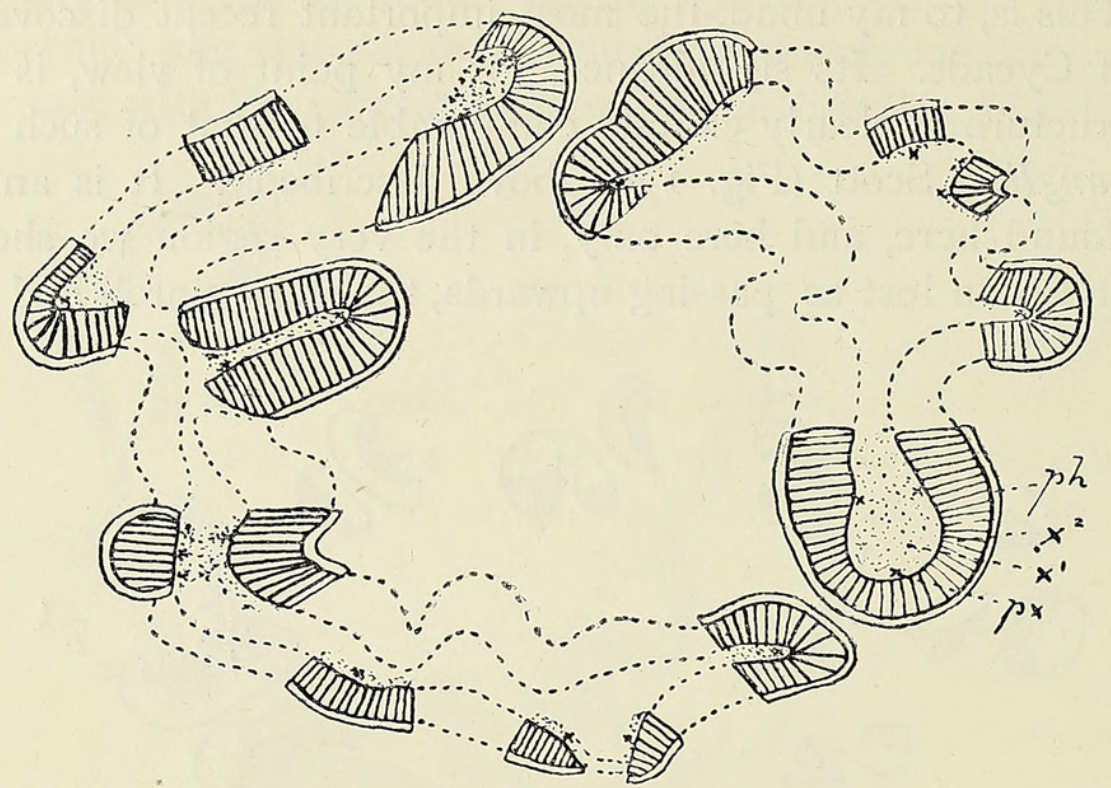

Fig. 3. Medullosa Leuckarti: transverse section of vascular system of stem, schematically drawn to represent how the vascular structure of Stangeria (illustrated above) could have been derived by fragmentation of the large irregularly shaped steles, the dotted outlines representing the eliminated portions.

that of $M$. Solmsii (Fig. 4), whose polystelic character I regard as probably derived from the solenostelic condition of such a form as $M$. porosa; on this view the structure of $M$. Leuckarti would represent a kind of intermediate stage between the two.

The incurved and horse-shoe-shaped bundles of Stangeria, I am convinced, possess a great phylogenetic and morphological significance: they are the remains of the concentric bundles or steles of the Medullosean

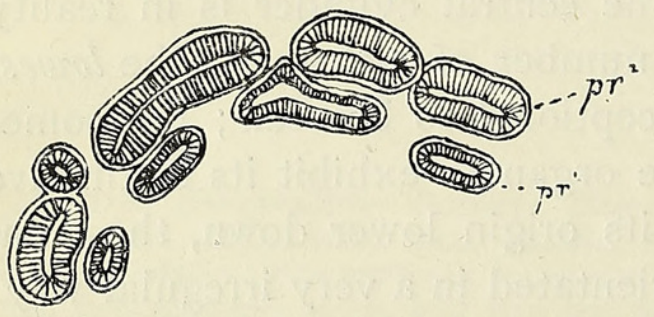

Fig. 4. Medullosa Solmsii: transverse section of part of double vascular ring of stem $; \mathrm{pr}^{1}=$ inner primary ring; $\mathrm{pr}^{2}=$ outer primary ring (reversed and in part restored) (after Weber and Sterzel). regard as an ancestral character, as its tardy appearance in the ontogeny would help to indicate. In the concentric and horse-shoe-shaped bundles of the lower region it is absent, the available space for such a tissue 
in the interior of those strands being reduced to a minimum. I regard these primary centripetal tracheides (whose rudimentary nature is further betrayed by the half-hearted way in which they assume the stain) as of probably dual origin: I hold that for the most part they represent the central primary tracheides of the stele of $M$. anglica; in this case we must imagine the protoxylem, centrifugal xylem and phloem of that part of the stele nearest the pith of the peduncle to have completely died away. Occasionally, however, these three tissues are present on the inner side of the bundle, while, in the wide area between them and the normal bundle, numerous 'centripetal' tracheides are seen. In such a case these inner tissues are well developed and not rudimentary in appearance; they merely represent an incurved portion of a horse-shoeshaped stele which has become detached and independent (Fig. 5). Such a strand sometimes anastomoses with the ventral portion of the bundle to which it is opposite. In other cases, however, a group of centripetal tracheides is united, on its pith-side, to an extremely rudimentary phloemstrand, or this latter may be replaced by a rudimentary cambium. It seems possible, therefore, that in some cases the 'centripetal xylem' may represent the vestiges of the centrifugal xylem (primary or secondary) of the ventral part of the original and primitive stele, the protoxylem belonging to which has become extinct.

As regards the mode of ontogenetic origin of all or any of these structures, it has probably

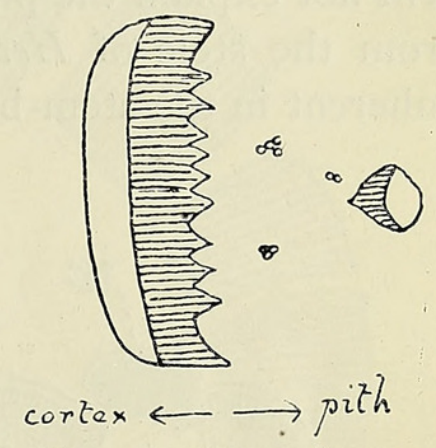

FIG. 5. Stangeria para. doxa: transverse section of a single bundle from vascular ring of peduncle, showing small strand on inner or pithside of large strand, with groups of centripetal tracheides lying between the two (diagrammatic). not the remotest connexion with their phylogenetic history. The chief point about this remarkable structure has hitherto been, apparently, missed.

Scott, however, lays great stress on his belief that the "centripetal' xylem, as found in the peduncle of Stangeria, Bowenia, and Ceratozamia, is the homologue and derivative of the centripetal primary xylem occurring in the bundles of the vegetative stem of Lyginodendron, Heterangium, Poroxylon, Calamopitys, \&c. In this we entirely concur. But we differ as to the mode of origin of the vascular tissue in these fossil plants. Scott regards the solid monostele of the Heterangium-type as the primitive form in this group; the Lyginodendron-type he holds to be derivative therefrom. According to his view the centripetal xylem of Lyginodendron represents the last peripheral remnant of the great mass of primary xylem which, along with parenchyma, occupies the entire internal area of the Heterangium-stele. My view, on the contrary, embodies the belief that each primary xylem-group in Lyginodendron, along with its mass of secondary centrifugal xylem and phloem, is the one-sided remnant of an entire stele 
or concentric bundle, and is hence precisely comparable to, and homologous with, each bundle in the peduncle of Stangeria, \&c. ; both, in my opinion, have been derived phylogenetically from a single stele, like one of those composing the cylinder of Medullosa. The following are my reasons for holding this isolated position. In many stems of Lyginodendron the bundles are more or less separate from one another, or in groups of two, due to lateral anastomosis; each single or double group of primary xylem having an arc-or fan-shaped mass of secondary xylem attached to it (Fig. 6); this in itself is an indication of the stelar origin of the bundle; otherwise, how is this arc-like character to be explained?

The fact that arc-shaped leaf-trace bundles are cut off from the cylinder (which may occasionally be concentric, thus resembling the case of Medullosa) will not explain the phenomenon; for similar arc-shaped leaf-traces pass off from the stele of Heterangium; the arc-shaped character is one which is inherent in the stem-bundles as such.

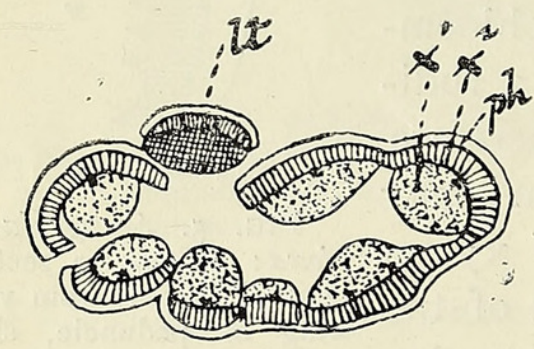

Fig. 6.

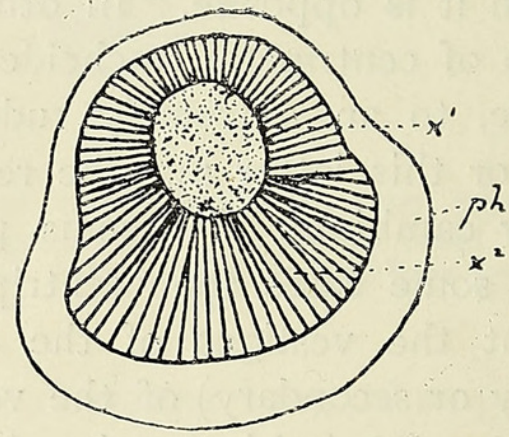

FIG 7 .

FIG. 6. Lyginodendron Oldhamium: transverse section of vascular ring of stem of young plant, $1 \mathrm{t}=$ leaf-trace (diagrammatic) (after Williamson and Scott). FIG. 7 . Transverse section of single bundle from vascular ring of stem, showing its concentric stele-like structure, the remaining bundles of ring had same structure (from slide no. II 38 of Williamson Collection in British Museum) (diagrammatic).

In some stems, however, where the bundles are more isolated, the cambium of the dorsal side extends right round the centripetal xylem on the ventral side (Fig. 7), though its secondary products in this region, as might be expected, are much less in amount, the parenchymatous often outnumbering the xylem-elements. This phenomenon strongly supports my position as to the polystelic origin of the Lyginodendron-cylinder. Scott, on the other hand, maintains that they do not in the least disturb his position as to the monostelic origin of the latter; for these extra tissues, giving rise to the concentric structure, are purely secondary, formed by a cambium which, in his opinion, may appear on the scene at any time and under any circumstances, and to which, therefore, no morphological significance is to be attached. He regards it as the same anomaly as occurs in Acanthophyllum (Caryophyllaceae), in Iodes tomentella (Olacineae), and in Tecoma (Bignoniaceae), and as far as the bare facts are concerned, these latter cases are, doubtless, comparable with that of 
Lyginodendron. In the case of Lyginodendron, the near allies of the plant, viz. Cycadoxylon ${ }^{1}$ and Medulloseae, exhibit this 'anomaly' as the normal structure in their stem. Hence, the comparative method of investigation strongly supports my hypothesis that this so-called 'anomaly' in Lyginodendron is a reversion to an ancestral character whose appearance is rendered possible by the late formation of interfascicular cambium in the stem. The isolated, sporadic, and (often) rudimentary characters of this 'anomaly' support my view; for these are precisely the features which distinguish ancestral structures wherever they appear.

I should, therefore, regard each bundle of the normal stem of Lyginodendron as itself the equivalent of a single complete stele in the stem of Medullosa anglica, of which the protoxylem, primary centrifugal, and secondary tissue belonging to the ventral or pith-side of the stele have completely vanished. I admit the bare possibility of what I cannot help regarding as a quite meaningless cambium appearing on the scene; but this mechanical view of the matter I regard, in the light of the facts cited above, with very much less favour than the one already given. Moreover, Scott, so it seems

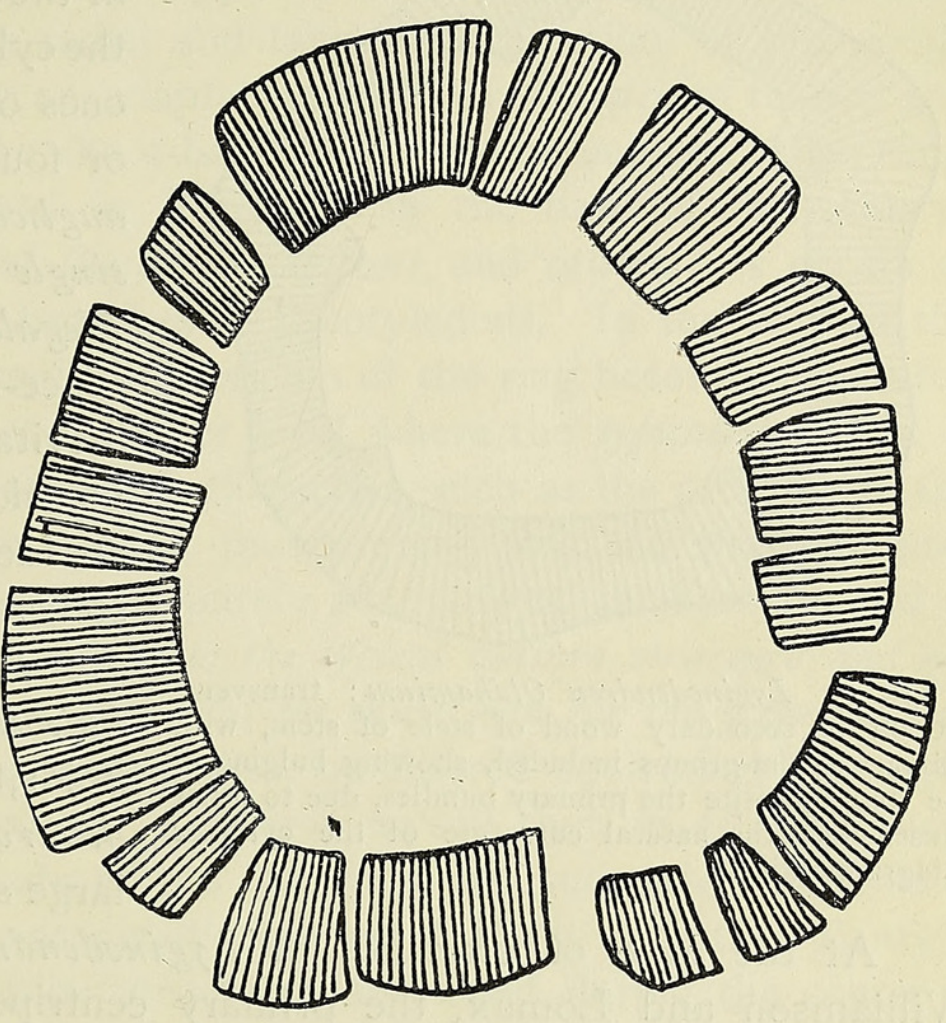

FIG. 8. Heterangium Grievii : transverse section of secondary wood of stele of stem, showing entire absence of any curvatures save those which are necessary for maintaining the cylindrical contour of the stele as a whole (diagrammatic).

to $\mathrm{me}$, is inclined to attach a far too great significance to the difference existing between primary and secondary tissues. In my opinion there is no essential difference between primary meristem and cambium, the difference merely lying in the varying periods at which they respectively arise, each having, in accordance therewith, its own peculiar characteristics. And the secondary tissue is one of the great and characteristic features of the group of plants with which we are dealing.

Owing to the even, uncurved contour of its ring of secondary xylem (Fig. 8) (so contrasted with that of the ring of secondary xylem in Lygino- 
dendron, in which the simuous ${ }^{1}$ character can always be more or less clearly traced, Fig. 9), and the character of the entire general structure, I regard the single large monostele of Heterangium and, I would add, of Megaloxylon, as equivalent to a single stele of Medullosa. The very sinuous contour of many Medullosean steles is due to two causes: firstly, to the perpetual anastomoses occurring between neighbouring steles, and secondly, to the constant abstriction of concentric leaf-trace and medullary bundles; but these two causes will not account for the sinuosity of the central

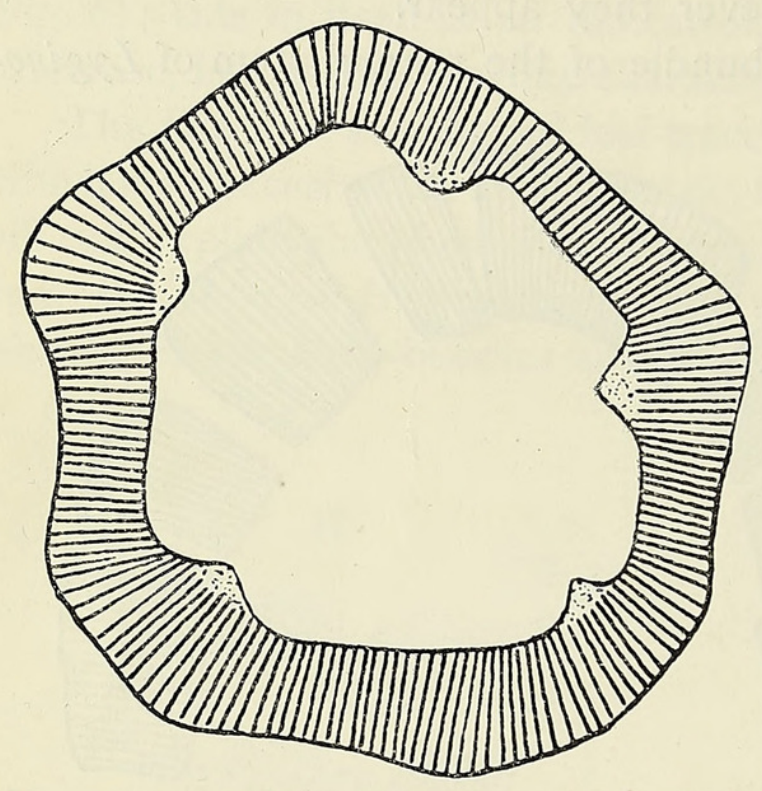

FIG. 9. Lyginodendron Oldhamium: transverse section of secondary wood of stele of stem, with primary xylem-groups included, showing bulging of the ring opposite the primary bundles, due to other causes than the natural curvature of the cylinder (diagrammatic). cylinder of Lyginodendron. There may be traced a gradual reduction in the number of steles composing the cylinder: ( $I$ ) the very numerous ones of $M$. Solmsii; (2) the three or four much larger steles of $M$. anglica or M. Leuckarti; (3) the single stele of Heterangium and Megaloxylon which, owing to space-relations, is naturally and inevitably of much greater dimensions than, while preserving an identity of structure with, the steles of other members of the group. Hence, on my view, each individual bundle and not, as Scott holds, the entire cylinder, of Lyginodendron, is the homologue of the large stele of Heterangium, \&c. ${ }^{2}$

At the bases of branches of Lyginodendron, as described by both Williamson and Lomax, the primary centripetal xylem-groups tend to become continuous (although complete continuity never obtains), while the

${ }^{1}$ Cf. Williamson's Figs. I, 2, 4 (Plate XXII), and 6, 7 (Plate XXIII), of Lyginodendron with his Fig. 30 (Plate XXVIII) of Heterangium (Organ. Fossil Plants of Coal-Meas., Part iv, 1873). Also Williamson and Scott's Fig. I (Plate XXI) and their Photo. I (Plate XVIII) of Lyginodendron in their joint paper of 1896 with Williamson's Fig. I (Plate XXI) in his memoir of 1887 . Williamson's Fig. 2 (Plate XXII) of the same memoir, showing part of the transverse section of the stem of Heterangium tiliaeoides, shows a somewhat sinuous contour of the ring, but it will be noted that even here the secondary xylem is never arched around each primary xylem-group as it always is in the case of Lyginodendron. Whenever a section of the entire cylinder is seen this striking fact becomes incontrovertible.

2 Any argument for the close affinity of Lyginodendron and Heterangium drawn from the fact that they both bore a Sphenopteroid type of foliage can have little weight in view of the fact that several forms of Sphenopteris-foliage belonged to the true Ferns bearing such fructifications as those named Renaultia, Discopteris, Dactylotheca, Oligocarpia.

Again, the stem of some species of Davallia is polystelic, that of other species is solenostelic, yet the same type of foliage obtains throughout the genus. It is not, therefore, very strange to find a considerable latitude in the character of the stelar anatomy of Pteridosprrms bearing Sphenopterisfoliage. 
pith becomes much smaller in diameter, the centripetal xylem occupying an important part of the area enclosed by the secondary wood. The latter tissue at the same level forms a continuous, compact ring in which the sinuous character is very much less evident than is the case at a higher level of the branch. The result of all this is a much greater resemblance of the structure of the branch-base to that of the mature stem of Heterangium than is the case with the structure at a higher level of the branch where the typical Lyginodendron-features reappear.

I do not regard this as having any phylogenetic significance, for the ontogeny of the structure of a shoot need not necessarily repeat its phylogenetic history. The explanation appears rather to be a mechanical one : the concentration, both in a radial and tangential direction, of the woody vascular tissues is probably an adaptation for the resistance of tension and bending-strains to which the shoot-base must become subject. The same adaptation may be observed in Ferns, as in the base of the stem of Osmunda, of the branches of Blechnum Spicant, and others. It occurs at the base of the stems and branches of Dicotyledons. In the base of the peduncle of Stangeria the centrifugal xylem of the ring becomes congested in this way, and it is only at a higher level, where the typical structure of the organ is assumed, that ancestral characters, such as the presence of the centripetal xylem, begin to appear, thus proving that the structure prevailing at the base of the organ is purely adaptational in character and of no phylogenetic significance. It is to the typical mature structure, and not to the early stages of its ontogeny, that we must look for the occurrence of ancestral characters. The subject cannot be entered upon now, but might well repay further investigation. I believe myself that, in all likelihood, far too much has been made of the idea that the successive anatomical structures exhibited in the ontogenetic history of Ferns and other plants is a repetition in parvo of similar structures developed during the course of the phylogenetic history.

Further evidence in support of the view set forth above as to the origin of the Lyginodendron-structure is afforded by the early occurrenceviz. in the Calciferous Sandstone-of that polystelic member of the same group we are considering, Cladoxylon. I may add, as a final corollary to this part of the subject, an opinion which I have elsewhere expressed: 'that the derivation of the tubular from the solid stele is to be sought for, not in these semi-gymnospermous forms, but much farther back, viz. among the Ferns!'

In Med. Solmsii and M. Leuckarti (some forms) the two primary rings of steles differ in that the steles of the innermost ring are smaller and less developed than those of the outer. In $M$. porosa there is also an inner ring which may be said to be formed by the regular anmular grouping of certain of the small medullary steles. In fact, transitions exist between 
the medullary system and the inner cylindrical system of steles. I hold, further, that in the Medulloseae the cylindrical and medullary systems are merely variants of a single system. That the annular or cylindrical system has either been derived in the past from a primitive system of irregularly scattered steles, of which the medullary strands are the surviving remnant; or, on the other hand, that the cylindrical system is primitive, and has itself given origin to the medullary system. I am inclined to regard the latter as the most probable view.

In most cases the medullary steles are perfectly concentric in structure, but this is not always so; e.g. in $M$. porosa the outermost, as also several of the more central, steles are imperfectly concentric; in such cases the resultant collateral or sub-concentric stele is very variously orientated, according as the secondary tissue is defective on this or that side of it.

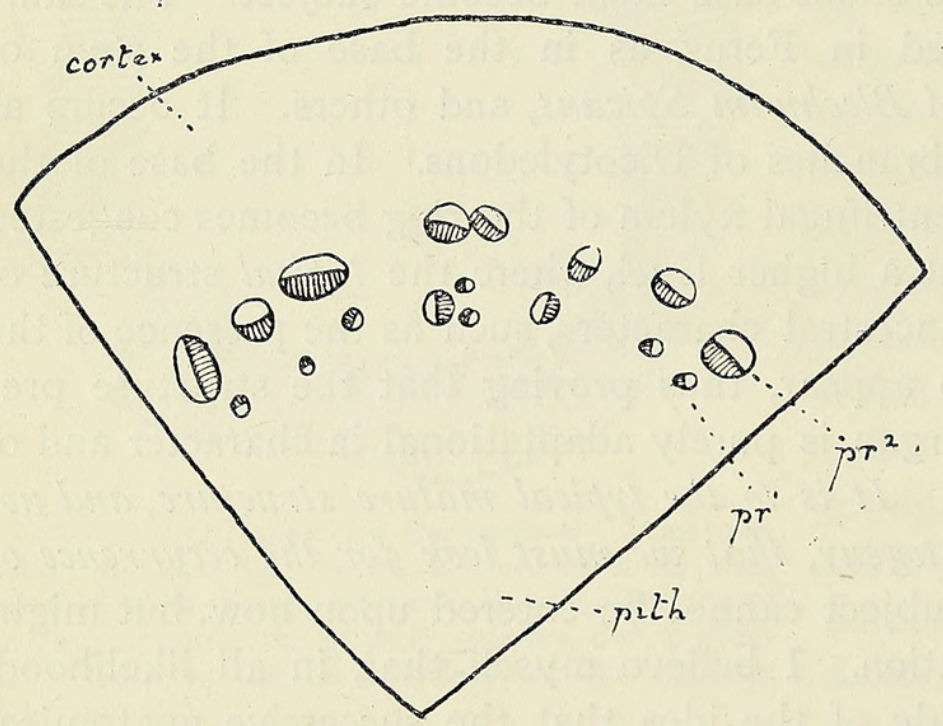

FIG. IO. Ceratozamia latifolia: transverse section of part of vascular system of fertile region of cone-axis, showing inner primary ring of small bundles (diagrammatic).

Now in the modern genera Encephalartos and some species of Macrozamia there is a medullary system of, usually, very small and very numerous collateral bundles of extremely various and irregular orientation; this latter may be primarily due to the causes just mentioned in the case of Medullosa; but appears more directly traceable to the fact that each bundle follows the sinuous course of a mucilage-duct towards which its phloem is always orientated. But the cauline origin of these medullary bundles may be attributed to the fact that they constitute one and the same system with those of the vascular rings.

In the fertile part of the axis of the male cones of Ceratozamia mexicana, Brongn., and C. latifolia, Miq., I observed the rudiment of an intrafascicular primary cylinder of bundles; these latter were much less developed than those of the outer cylinder; they were in one of the species arranged frequently in small groups of three (Fig. IO), representing small fragmented concentric structures, for their xylems were mutually orientated towards each other; other isolated bundles were inversely orientated; in the other species the inner bundles were much less numerous and usually rudimentary in development, staining badly; one such was observed to be perfectly concentric in structure and to end blindly upwards. In both 
cases I regard these inner bundles as an ancestral remnant of the innermost cylinder of primary bundles above described in certain Medulloseae. The same will hold good for the two primary cylinders in the peduncle of the cone in Encephalartos, of which the outermost, divided up into irregularly formed groups of concentrically-arranged bundles, supplies the sporophyll-traces. Matte gives beautiful illustrations of this pleiocylindric character in the peduncle of the cone of Encephalartos villosus (Fig. II).

The inversely orientated strands occasionally occurring on the dorsal side of the bundles of the normal cylinder or arc of the peduncles and sporophylls respectively, receive also their explanation from a study of Medullosean anatomy. This phenomenon is due to the presence in that position of a stele, or the rudiments of such, which, instead of, as in the case of the usual bundles of the cylinder or arc, lacking the ventral portion of the primitive stele, exhibit a complete abortion of the dorsal half thereof. But in one or two cases, signs of slight cambial activity on the outer side of such strands indicate an attempt at reversion to the primitive state of things. Frequently these strands are continuous

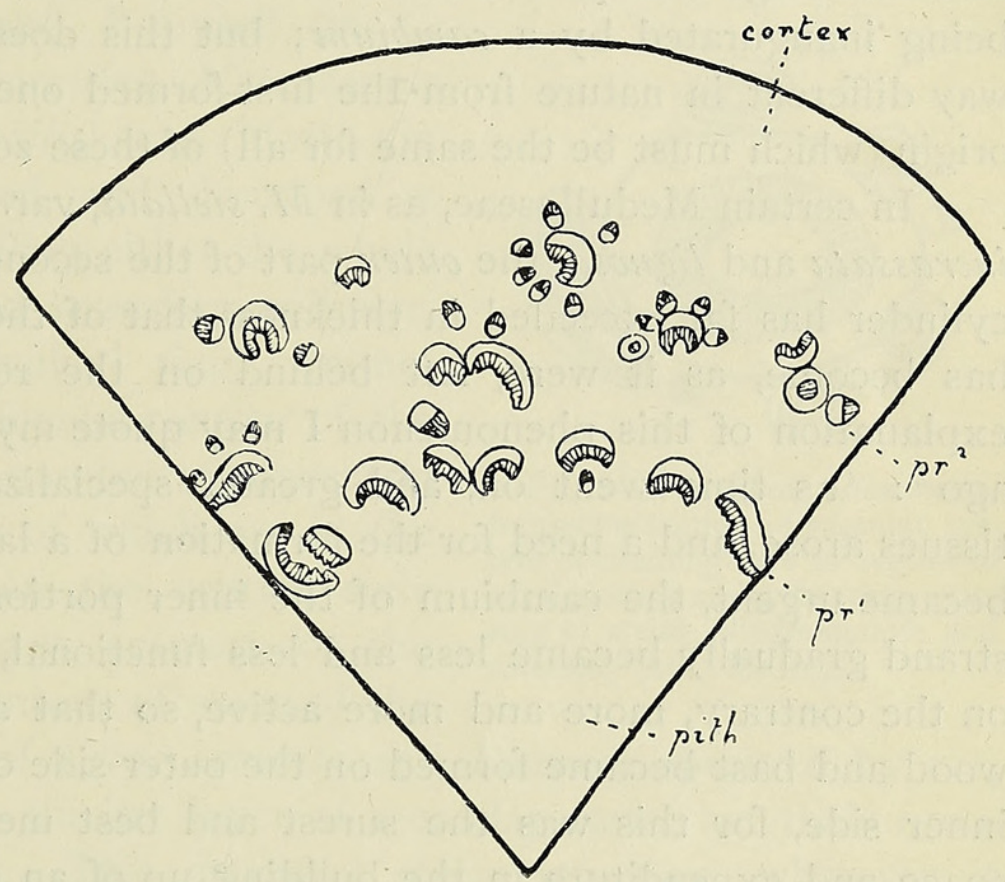

Fig. II. Encephalartos villosus: transverse section of part of vascular system of peduncle of cone, showing outer primary ring consisting of groups of bundles (after Matte) (diagrammatic).

with those of the normal cylinder by means of an involution of their tissues; this is also the same phenomenon as was described by Gregg in the root of Cycas Seemanni; in that case, however, the outer half of the usually incomplete stele is present, and is continuous as an independent continuous zone right round the entire root-stele.

In the case of the cone the inversely orientated dorsal strands are primary; hence we here see another instance of the presence of two primary cylinders (or parts of such) like those already described. As a comparison with what I found in the case of Encephalartos, we may note that Scott says, speaking of Ceratozamia: 'some of these [inverted cortical] bundles, where they pass further out into the cortex, show some 
approximation to a concentric structure 1'. Here we see clearly preserved in the cone-axis traces of a second cylinder. This latter has long since disappeared from the vegetative axis, Ceratozamia being one of the monocylindric forms.

Let me now pass to the consideration of the 'extrafascicular' secondary strands and zones; they occur, as mentioned above, in the stem of four genera of modern Cycads, and in that of Medullosa stellata, var. gigantea. The structure of this latter is almost exactly a replica of that of a modern Cycad which possesses it. I will therefore consider them together. At the outset I may say that I regard all the cylinders or rings as mutually homologous, and that there exists no morphological distinction between the primary and secondary zones. The comparatively late period at which all vascular rings except the first arise necessitates their earliest beginnings being inaugurated by a cambium; but this does not render them in any way different in nature from the first-formed one. What is, therefore, the origin (which must be the same for all) of these zones?

In certain Medulloseae, as in $M$. stellata, var. lignosa, $M$. Solmsii, vars. incrassata and lignosa, the outer part of the secondary wood of the primary cylinder has far exceeded in thickness that of the innermost portion which has become, as it were, left behind on the road of advancement. In explanation of this phenomenon I may quote my own words of nine years ago ${ }^{2}$ : 'as time went on, and greater specialization in the conductingtissues arose, and a need for the formation of a larger amount of this tissue became urgent, the cambium of the inner portion of each such concentric strand gradually became less and less functional, that of the outer portion, on the contrary, more and more active, so that a much larger quantity of wood and bast became formed on the outer side of each strand than on the inner side, for this was the surest and best means of economizing both space and expenditure in the building up of an efficient conducting-tissue for the stem.'

The primitive condition, in which the secondary wood was of equal development all round or on both sides, is seen in the polystelic cylinder of $M$. Solmsii (Fig. 4), and in the solenostelic cylinder of $M$. porosa respectively.

In the case of the Medulloseae the innermost part of the secondary wood of the primary ring, never, as far as we know, became extinct; in modern Cycads, on the contrary, it became, along with the phloem (except in the case of Encephalartos Barteri, described above), completely extinct.

As regards the outer secondary rings, it is a remarkable fact that these, in the stem of Med. stellata, var. gigantea, had, apparently, already com-

1 Matte describes the same phenomenon in the peduncle of Bowenia and Ceratozamia. In the latter he also figures concentric and arc-shaped bundles in this position.

${ }^{2}$ Dec. 1896. 
pletely lost their inner inverted secondary tissues; this is, possibly, also the case with $M$. Solmsii, var. lignosa. That the primitive type possessed two or more solenosteles of secondary origin we do not know. It is possible that these outer secondary zones may have been collateral in structure from the beginning, but this, in the light of the structures presently to be described in some Cycads, is not probable; yet even if it were so, these zones would still have to be regarded as morphologically equivalent to the outer or dorsal half of a solenostele, and, therefore, these 'extrafascicular' collateral cylinders are morphologically derived from solenosteles, owing to the fact that the primary ring possesses the structure of this latter; and all the rings are to be regarded as homologous.

Let us consider now the case of the Cycadaceae. In that most primitive part of the axis of the plant (see supra), viz. the cotyledonary node, Gregg (in Cycas Seemanni), I myself (in $C$. revoluta, Encephalartos horridus, Macrozamia Denisonii, Bowenia spectabilis), and Matte (in Cycas siamensis), observed and described a polystelic structure controlling either the whole or part of the first-formed secondary cylinder, i. e. the first 'extrafascicular' ring. Immediately outside the very sinuous contour of the root-stele Matte figures a number of concentric structures or steles, some of which are in the act of separating off from the central stele (Fig. I2); this will, perhaps, account for the imperfect continuity of contour of some of the

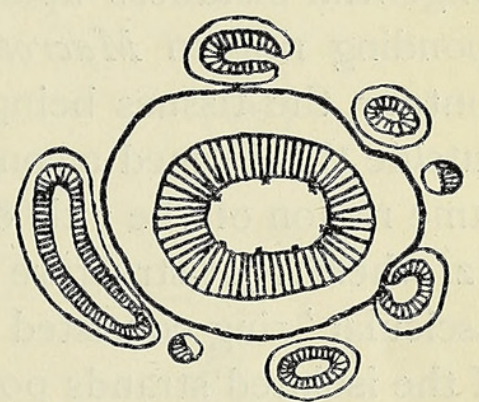

FIG. I2. Cycas siamensis: transverse section of vascular sys. tem of seedling-axis in region of cotyledonary node, showing outer ring of steles (diagrammatic and reversed) (after Matte). steles. As in the cases of Cycas revoluta and Bowenia observed by me, some of the steles have a thicker layer of secondary wood on their inner than on their outer side. This ancestral stelar structure, wherever it occurs, becomes replaced, higher $u p$ in the axis, where modern tendencies hold supreme sway, by a contimuous, collaterally-constructed cylinder; if traced downwards into the root these steles merge into the central cylinder. In the mature plant all trace of these structures in the cotyledonary node would probably be lost.

In Encephalartos horridus I observed ' on the dorsal side of, and closely. abutting on the large [concentric] strand [of the first "extrafascicular" cylinder] ... two other smaller ones of the ordinary collateral structure and orientation. At another level two strands are seen, one on each side of the large one, each with a considerable amount of secondary thickening, one of which has inverted orientation.' 'Further out in the cortex are scattered other much smaller bundles with inverted orientation. Another group of three bundles was observed, with their xylems mutually directed towards each other.' These smaller strands I regard as the first sporadic 
beginnings of the second, third, and fourth 'extrafascicular' cylinders respectively; it will be noted that two of them exhibit traces of the primitive concentric or stelic structure.

In the basal region of a mature stem of Macrozamia Fraseri I observed small, rudimentary inverted strands on the inner side of the first and second 'extrafascicular' rings; these, doubtless, represent the corresponding portion of the concentric strands which were seen to occur immediately outside the central cylinder in the same region of the stem in a young plant of $M$. Denisonii; they are very interesting as showing how such ancestral and (for modern requirements) unnecessary parts of the structure become swamped and rendered utterly obscure as individual growth proceeds.

In the same region of the stem of Cycas Seemanni I found the first 'extrafascicular' ring to be composed of concentric strands situated at wide tangential distances apart, which differed from those composing the corresponding ring in Macrozamia and Encephalartos in having a symmetrical contour, the tissues being of the same thickness all round; the ring next outside this formed a continuous zone having a collateral structure. In the same region of the axis of another individual but at a slightly lower level, viz. where root-structure of the central cylinder occurred, the first 'extrafascicular' ring consisted of a much broken-up collateral zone; one or two of the isolated strands possessed an almost equal amount of inverted xylem and phloem on the inner side. The second extrafascicular ring is a continuous thick collateral zone with, at intervals, some extremely minute, rudimentary, inverted bundles on its inner side; these represent the last faint traces of the former solenostelic structure of this ring. The third ring exhibited much the same characters as the first.

In all species of Cycas the stem possesses throughout its length a cortical system of perfectly concentric secondary strands which are cauline, terminating above in the base of a leaf and connected, during their course, with incoming leaf-traces. They appear to be peculiar to the genus Cycas, and to have no exact counterpart in the Pteridosperms. In any case, they are interesting; for they constitute an outlier from the main conductingsystem of the stem, and hence have escaped all those modern influences which have reduced the ancestral concentric structure of the main rings for the most part to the collateral type. This outlying ring of concentric strands resembles precisely the first 'extrafascicular' ring of strands observed by me in the case of the stem of $C$. Seemanni, and also the 'accessory vascular strands' described by Scott in the stem of Med. anglica. In all these cases the central, irregularly-scattered tracheides, which so greatly resemble primary elements, are in reality the first-formed secondary tracheides of the wood of the stele. The same isodiametric elements can be found on the inner side of the 'extrafascicular' collateral rings in all Cycads which possess them. 
There thus appears a mass of clear and conspicuous evidence in favour of the derivation of both the primary and the secondary endarch rings or cylinders of Cycadean stem-organs, from the poly- or solenostelic structure of the same organs in the Medulloseae. The hypothesis of the appearance on the scene of a meaningless cambium in order to account for the inverted ventral strands, I find myself quite unable to accept.

\section{Origin of Foliar Structures.}

The Fern-like character of the foliage of the Pteridosperms we found to be still represented in that of certain of our modern Cycads. We should therefore expect to find in the anatomy of the foliar organs of Cycads further indications of their Pteridospermic ancestry.

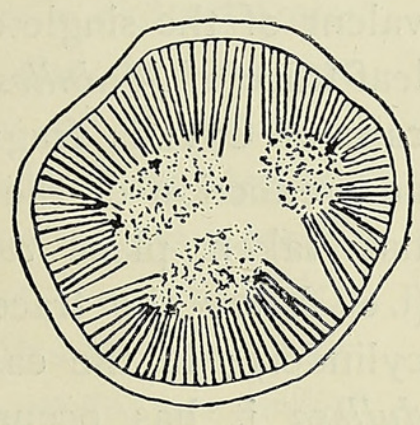

FIG. I3.

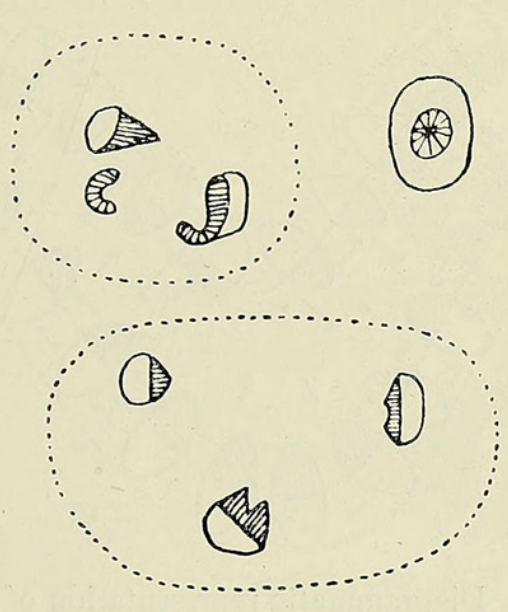

FIG. I4.

Fig. 13. Medullosa stellata: transverse section of leaf-trace bundle just after leaving central cylinder, showing the three component parts into which it eventually splits (diagrammatic and partially restored) (after Weber and Sterzel). FIG. I4. Stangeria paradoxa: transverse section of three sets of leaf-traces, two of which are broken up into their constituent strands, the other being entire (diagrammatic).

Firstly, I may refer to the structure of the vascular bundles. In Medullosa the leaf-trace bundles on leaving the central cylinder of the stem are perfectly concentric (Fig. I3), but shortly each breaks up into a number of collateral strands. In Lyginodendron and Heterangium the bundle only assumes the concentric structure after entering the leaf, where refusion of the two, which were the result of division of the leaf-trace in the pericycle, takes place. But in certain stems of Lyginodendron some of the leaf-trace bundles were perfectly concentric in structure.

Now I observed in the peduncle of the female cone of Stangeria that some of the sporophyll-traces immediately on leaving the central cylinder appeared in the form of three separate small bundles grouped around a common centre, so that such a group may be said to represent, as it were, a fragmented concentric bundle. Further out in the cortex these bundles became completely separated from each other. In the 
outer part of the cortex one or two of the bundles supplying the barren sporophylls possessed three distinct groups of xylem; this is probably a relic of a similar tripartite bundle as that above described and as is also found in Medullosa. Quite frequently a perfectly concentric sporophyll-trace occurs in the neighbourhood of other collateral traces and too far out in the cortex to belong to the cauline system of strands (Fig. I4). Here, then, we see some last obscure remnants of the ancestral leaf-trace bundles in precisely that part of the plant where we should most expect to find them.

In Cycads the leaf-traces leave the cylinder, as a rule, in groups of two ${ }^{1}$; in the peduncle of Encephalartos villosus Matte observed groups of three to five leaf-trace bundles passing out. The bundles have very often

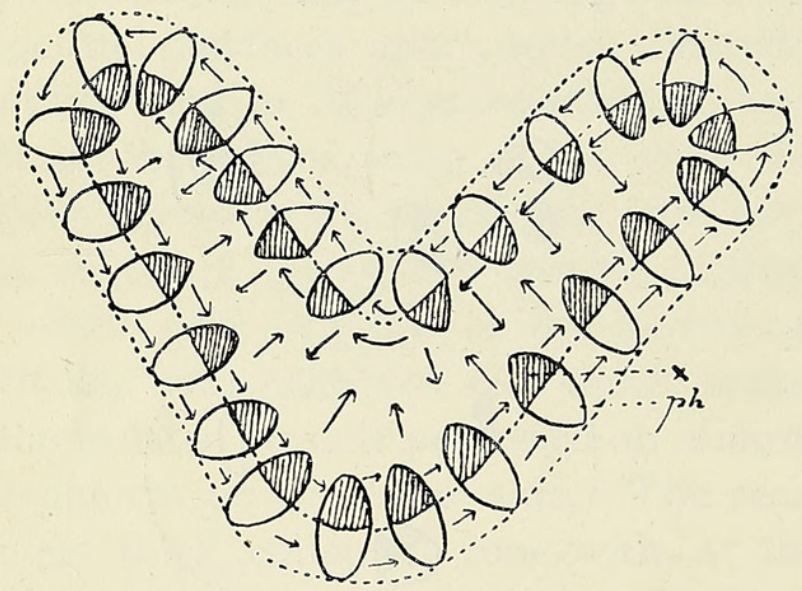

FIG. I5. Diagrammatic representation of method of derivation of the numerous, separate, collateral bundles of petiole of Cycads from the single, large, concentric bundle of petiole of Lyginodendron, \&c. (transverse section). their xylems slightly directed towards each other. Each group of one, two, or more may be regarded as the equivalent of the single concentric leaf-trace of Medullosa; in the case of Cycads fragmentation and reduction of the leaf-trace has taken place congenitally (i. e. before the trace left the cylinder); in the case of $M e$ dullosa it has occurred postgenitally (i. e. since leaving the cylinder).

The bundles in the petiole of, e. g. Encephalartos, are precisely identical, both as regards orientation, number, and individual structure, with those of Myeloxylon. The similarity, indeed, is so close as to render an homology between the two systems of bundles practically certain. If this be admitted, it must then of necessity follow (a conclusion which appears hitherto to have been completely overlooked) that the vascular systems of the stems of Medullosa and Cycads respectively must also be homologous. And if this be so, what becomes of the theory which regards the Cycadean central cylinder as having been derived from the single Heterangium stele?

At first sight it would seem as if no relation whatever existed between the vascular structure of the leaf-petiole of Lyginodendron or Heterangium and that of the same organ in Medullosa and the Cycads. The single ${ }^{2}$

1 In the case of the male sporophyll a single bundle leaves the cone-cylinder which subsequently in the cortex branches into two.

${ }^{2}$ In some cases there are two bundles. 
large bundle of Lyginodendron, with its several protoxylem-groups situated in a mesarch position, really, in my opinion, corresponds to, and is the equivalent of, a number of collateral mesarch bundles united together by means of their centripetal xylems, their phloems likewise fusing and surrounding the whole. If we imagine each of these primary centres separated, each constituting a distinct bundle and at the same time retaining its position, they would be seen to roughly exhibit the horse-shoe-shaped grouping so characteristic of most Cycads (Fig. 15). This grouping most closely resembles that of the bundles in the petiole of Stangeria; and this is interesting, for the foliage of Stangeria is the most Fern-like of all Cycadian leaves (Fig. I6). The extreme case of subdivision of such a Rachiopteris-strand is seen in the petioles of Medullosa (Myeloxylon) and certain species of Encephalartos (e. g. E. cycadifolius) where an enormous number of separate collateral bundles exist, orientated in a variety of directions. But in $E$. horridus we note a case which, in my opinion, represents a distinct transition to the monodesmic condition of Lyginodendron; for here the vascular system represents a modification of the $\Omega$ in which the bundles are fusing together in groups in a radial direction, i. e. towards the centre of the organ, to form small, usually. imperfectly,
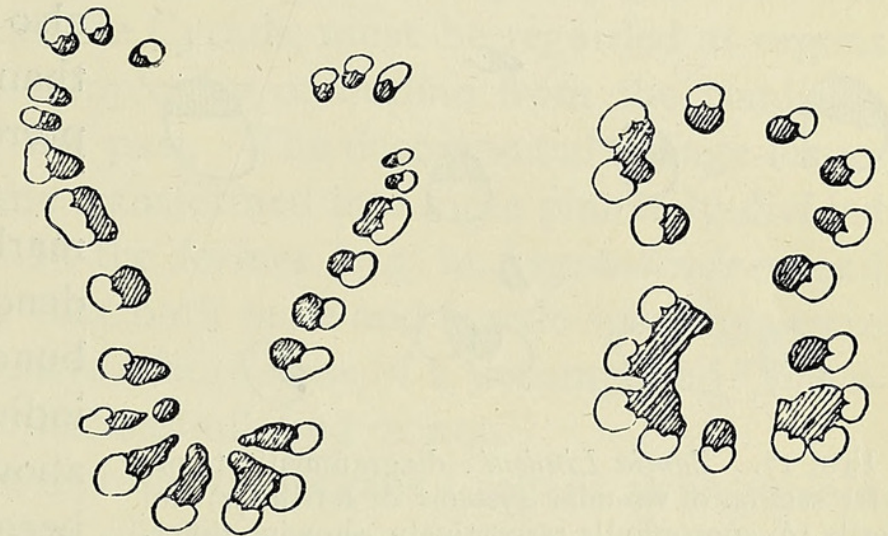

FIG. I6. Siangeria paradoxa: diagrammatic transverse section of vascular system of petiole, showing lateral fusion of bundles (after Matte). concentric strands. We

have only to imagine this phenomenon proceeding still further in order to obtain a petiolar vascular system consisting of one or two large concentric bundles as in Lyginodendron. In the case of Stangeria we see lateral fusion between the bundles taking place, which, of course, would also be necessary in order to build up the primitive large concentric strand; so that I am inclined to regard all these examples of fusion as reversions to an ancestral condition (Fig, 16).

If the view here set forth be adopted the two sets of petiolar vascular systems represented by Cycads on the one hand and Lyginodendron and Heterangium on the other, become easily related and harmonized. Ever since I first observed them, some nine years ago now, I have always regarded the mesarch collateral bundles of the Cycadean petiole as a remnant of a former concentric strand possessing a central mass of centripetal xylem in the common, far-back ancestors of the Cycads and the Medulloseae. I regard the single polyarch bundle of Lygino- 
dendron, \&c., as the most primitive of the two types of petiolar bundlesystems, for the simple reason that it is the most Fern-like; one has only to recall the single, concentrically-constructed petiolar bundles of such Ferns as Zygopteris, Osmunda, Ophioglossum, \&c., to render this view reasonable.

The fact that the leaf-trace of Medullosa, on its first leaving the vascular system of the stem, is a single concentric bundle which subsequently becomes fragmented into a number of collateral bundles, each having precisely the structure of the petiolar bundles of modern Cycads, is further evidence as to the original ancestral character of the petiolar vascular system of these modern plants ; this is another good example of the first-formed tissues in the ontogeny exhibiting ancestral characters, for we must regard the lowest part of the leaf-trace as, ontogenetically, the most primitive.

The Sphenopteroid foliage of Lyginodendron and Heterangium may

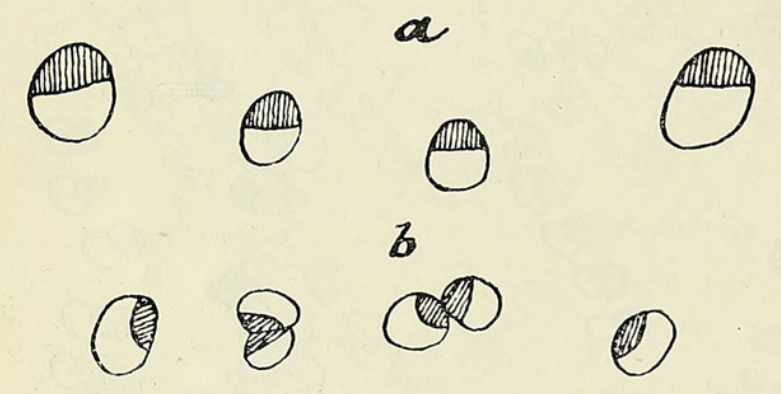

FIG. 17. Zamia Lindeni: diagrammatic transverse section of vascular systems of fertile $(a)$ and sterile (b) sporophylls respectively, showing difference in orientation and structure of the strands in the two systems. also be said to be tess Cycad-like than the Alethopteroid and Neuropteroid foliage of the Medulloseae.

Another point is worth remarking: there is always a tendency for the separate collateral bundles, which I regard as the individual units resulting from the above-described fragmentation, to become each one concentric in structure, as if partaking of the character of the parent-bundle in the stem from which they sprang. This is the probable cause of the arcshaped phloem of all foliar bundles in Cycads. Hence the concentric bundles of the cotyledons of Stangeria and Bowenia, of many sporophylls and, in some cases, of the integuments.

It is not unlikely that in the vascular systems of the petioles of the Cycadophyta ${ }^{1}$ all stages and types occur between the single large concentric bundle of Lyginodendron, \&c., and the numerous collateral bundles of Myeloxylon, just as in the vascular system of the stems of the Medulloseae and Cycads the types range from the single solenostele of $M$. porosa, through the ring of numerous concentric bundles or steles, to that of the numerous collateral strands of a modern Cycad.

In the case of the sporophylls the primitive concentric structure tends wholly to disappear, as a rule, in those bundles which are functional

1 I am here using this term, for the first time, in a new sense, viz. to include the Pteridosperms, the Mesozoic Cycadales, and modern Cycads; whereas Nathorst's use of the term included only the two latter groups; the Cordaites are, for the time being, at any rate, left out of consideration. 
in supplying the sporangia. The others, however, generally show some sign of it. It is highly interesting to find that the sterile sporophylls at the base of the cone contain bundles which, no longer compelled to submit to the above-named adaptive modification, revert back and tend to assume the concentric structure of the past (Fig. I7).

The girdle-like character of the leaf-trace system in the stems of modern Cycads is a recently-adopted modification; for in the Medulloseae and Lyginodendron, as also in the Bennettiteae, the leaf-traces pursue a directly radial course to the cylinder; I noticed with much interest that this was also the case with the traces passing in from the cotyledons in a seedling of Cycas; and the same thing is seen in the case of the sporophyll-traces of the cones. These four sets of facts prove that the radial course of the leaf-traces is the ancestral condition of affairs.

As regards the morphology of the foliar organs and the mode of insertion of the sporangia : both foliage-leaves and sporophylls, in view of the Pteridospermic ancestry of the Cycads, must be regarded as organs which have become reduced in complexity of outline from the condition of the Fern-like foliar organs of the past. The decompound foliage-leaves of the Pteridosperms have become transformed into mere pinnately-divided organs in the modern forms ${ }^{1}$. In the former (e.g. in Lyginodendron and Neuropterideae) it would appear that both male and female sporangia were borne as terminal organs on ultimate subdivisions of a decompound ${ }^{2}$, dorsiventral foliar organ which was either assimilating or not.

This terminal position of the reproductive organs I regard as an ancient primitive character, a reminiscence of the remote period when not only these ultimate ramifications of the sporophyll, but the entire organ itself, possessed radial symmetry ${ }^{3}$; for I follow Čelakovsky's view that all foliar organs, including even such highly complex dorsiventral forms as the Fern-leaves, have sprung originally from the sympodially-grouped reproductions or repetitions of a bryophytic sporogonium. Traces of this primitive character may still be found in some of the recent Ferns, such as Hymenophyllaceae, Schizaeaceae, Cyatheaceae.

In the group Bennettiteae the radial symmetry in the female sex is possessed by the entire sporophyll bearing the seed in a terminal position. Whether this ' cone,' considered in its entirety, is a reduced or a primitive structure we have, at present, no means of determining. On the male side the sporophyll appears to possess a dorsiventral structure with superficiallyplaced sporangia. In Cycadospadix the sporangia on the female side also seem to occupy a superficial position.

1 Cycas Micholitzii, Dyer, recently imported from Annam, differs from all other known species of that genus in possessing repeatedly-dichotomizing pinnae, and hence probably represents a more ancient type of leaf than the ordinary simply pinnate form.

2 Possibly some were of much simpler conformation.

${ }^{3}$ Cf. male and female sporophylls of Cordaiteae. 
Having regard to the Neuropteridean affinities of modern Cycads I should consider their cones as the final result of an extreme reduction of the erstwhile complex sporophylls, combined with a compact aggregation of these latter on a special portion of the main axis of the plant ${ }^{1}$. The sporophylls still retain a dorsiventral symmetry. On the female side the sporangia may be said to have just lost their primitive terminal position, for they are no longer on the actual margin but on the lower surface of the sporophyll. On the male side they are situated entirely on the lower surface, with no suggestion of a former marginal position, except in the case of Zamia, where they occupy much the same position as do the ovules on the female side. The genus Cycas is of great interest, for whereas the male sporophylls are reduced and arrayed in a cone, as in other genera, the female sporophylls constitute appendages of the vegetative portion of the stem. They are distinctly leaf-like, bear rudimentary pinnae in their upper portion, and a larger number of ovules than in the case of other genera. These ovules are also more primitive both as regards their size and also as to their position on the sporophyll, for they are borne terminally on extremely short, lateral outgrowths of the rachis, which may be regarded as the equivalents of the pinnae in the upper portion of the organ. Hence we may consider the female sporophyll of Cycas as approaching much more closely that of its Pteridospermic ancestor than is the case with other Cycads.

I formerly regarded the question as to the origin of the Cycadean sporophylls from a much too general standpoint. From the point of view of plant-evolution as a whole, I believe my statements will still hold good, but will require some modification as regards the minor cycle of evolution which concerns the Cycads alone. In 1898 I stated that 'the original type, viz. that in which the sporangiferous organs were distinct from the assimilating leaves, probably persisted right through, even down to the present day. From such forms as these latter I imagine it to be quite conceivable, and even probable, that modern Cycads took their origin.' In the light of recent discoveries as to the origin of Cycads this statement must now be retracted.

In conclusion, I may say one word as to the morphology of the ovular envelopes. I must side wholly with Čelakovský in maintaining that the law of uniformity demands that throughout Gymnosperms, to say nothing of higher and lower plant-forms, the sporangium must possess two integuments or the equivalents of such. In the ovule of Cycads there is no obvious representation of these; yet the comparison of the seeds of allied forms, both fossil and recent, show that two integuments are probably present, although so intimately and congenitally concrescent as to give to the whole envelope the appearance of a primæval integrity. In Lagenostoma, the

\footnotetext{
1 This may have also happened in the case of Bennettites on the lateral branches.
} 
seed of Lyginodendron, as also in that of Neuropteris heterophylla, the outer integument is probably represented by the detached cupule, while the inner integument itself is a hard sclerotic envelope. In Trigonocarpus there was an outer fleshy laýer concrescent with an inner bony envelope, just as in modern Cycads. The same was also probably the case with Stephanospermum.

In Taxus the fleshy layer is detached in the form of an aril. Hence I am led to regard the outer fleshy layer in the ovule of Cycads as representing the outer integument, and the sclerotic layer and inner softcelled tissue as together constituting the inner integument.

\section{BIBLIOGRAPHICAL.}

Arber : On some new species of Lagenostoma. Proc. Roy. Soc., ser. B, vol. 1xxvi, I905.

BARY, A. DE : Notizen über die Blïthe einiger Cycadeen. Bot. Zeit., 187o.

I88. Comparative Anatomy of the Vegetative Organs of the Phanerogams and Ferns.

Benson, M.: On Telangium Scotti. Ann. Bot., vol, xviii, 1904.

Bertrand and Renault : Remarques sur les faisceaux foliaires des Cycadées actuelles et sur la signification morphologique des tissus unipolaires diploxylés. Arch. Bot. du Nord, vol. ii, I $882-6$. houillers supérieurs. Id.

: Recherches sur les Poroxylons, Gymnospermes fossiles des terrains

Bower : On the Comparative Morphology of the Leaf in Vascu'ar Cryptogams and Gymnosperms.
Phil. Trans., vol. clxxv, I 884.

Bower : On the Comparative Morphology of the Leaf in Vascu'ar Cryptogams and Gymnosperms.
Phil. Trans., vol. clxxv, I 884.

BkAUN : Die Frage nach der Gymnospermie der Cycadeen, erläutert durch die Stellung dieser Familie im Stufengang des Gewächsreiches. Monatschr. k. preuss. Akad. d. Wiss., 1875.

: Ueber zwei von Hildebrandt angeführte Cycadeen nebst Bemerkungen iiber einige andere Cycadeen. Sitzber. Ges. naturf. Freunde zu Berlin, 1876 .

Brongniart, AD.: Recherches sur l'organisation des tiges des Cycadées. Ann. d. Sc. Nat., sér. I, vol. xvi, 1829 . vol. v, 1846 .

: Note sur un nouveau genre de Cycadée du Mexique. Ann. d. Sc. Nat., sér. 3, : Les graines silicifiées. Paris, $188 \mathrm{r}$.

BUCKLAND: On the Cycadeoideae, a Family of Fossil Plants found in the Oolite Quarries of the Isle of Portland. Geol. Trans. of London, ser. 2, vol. ii, I 828 .

Capellini and Solms-Laubach : I tronchi di Bennettitee dei musei italiani. Mem. d. R. Accad. d. Sc. d. Istituto di Bologna, ser. 5 , vol. xii, 1392 .

Carruthers : On some Cycadean Fruits from Secondary Rocks of Britain. Geol. Mag., vol. iv, 1867.

: On Beania, a new Genus of Cycadean Fruits from the Yorkshire Oolites. Geo!. Mag., vol. vi, 1869 .

: On Fossil Cycadean Stems from the Secondary Rocks of Britain. Trans. Linn. Soc., vol. $x x v i, 1870$. 
ČElakovský: Die Gymnospermen: eine morphologisch-phylogenetische Studie. Abhandl. d. königl. böhm. Ges. d. Wiss., vol. iv, 1890 .

: Nachtrag zu meiner Schrift über die Gymnospermen. Engler's Bot. Jahrb. f. Syst. etc., vol. xxiv, I897.

СонN : Ueber einen reifen Fruchtzapfen von Encephalartos Lehmanni. Sitzber. d. bot. Sect. d. schles. Ges. für vaterland. Cultur im Jahre I 89 I.

Constantin and Morot: Origine des faisceaux ligneux surnuméraires des Cycadées. Bull. Soc. Bot. de France, vol. xxxii, I 885.

Coulter and Chamberlain: The Morphology of the Flowering Plants. Part I : Gymnosperms.

Engler and Prantl : Die natürlichen Pflanzenfamilien. Part II, vol. i, Leipzig, r889.

Feistmantel: Ueber die Nœggerathien. Sitzber. k. Ges. d. Wiss. Prag, i 8 79.

Goeppert : Die fossile Flora der Permischen Formation. Palaeontographica, vol. xii, I864.

Goeppert and Stenzel: Die Medulloseae, eine neue Gruppe der fossilen Cycadeen. Palaeontographia, vol. xxviii, I88I.

Grand' Eury: Sur les graines trouvées attachées au Pecopteris Pluckeneti, Schlot. Comptes rendus, vol. cxl, April, 1905 .

- Sur les graines de Sphenopteris, sur l'attribution des Codonospermum et sur l'extrême variété des graines de fougères. Comptes rendus, vol. cxli, Nov. $190_{5}$.

GregG: Anomalous Thickening in the Rcots of Cycas Seemanni. Ann. of Bot., vol. i, 1887.

Hooker, Sir J.: On Trigonocarpons contained in Nodules of Limestone. Phil. Trans. Roy. Soc., vol. cxlv, 1855 .

Ikeno: Zur Kenntniss des sogenannten centrosomähnlichen Körpers im Pollenschlauch der Cycadeen. Flora, vol. lxxxv, 1898 .

- Vorläufige Mittheilung über die Spermatozoiden bei Cycas revoluta. Bot. Centralbl., lxix, I877.

: Untersuchungen über die Entwickelung der Geschlechtsorgane und den Vorgang der Befruchtung bei Cycas revoluta. Pringsh. Jahrb., vol. xxxii, I 898 .

Jeffrey, E. C.: The Structure and Development of the Stem in the Pteridophytes and Gymnosperms. Phil. Trans. Roy. Soc., London, ser. B, vol. cxcv, 1902.

Juranyi : Bau und Entwickelung des Pollens bei Ceratozamia. Pringsh. Jahrb., vol. viii, 1872.

KARSTEN : Organographische Betrachtungen der Zamia muricata. Abh. d. Berl. Akad. zu Berlin, $18{ }^{6} 6$.

KIDston : On the Fructification of some Carboniferous Ferns. Quart. Journ. Geol. Soc., I 884. : On the Fructification of some Ferns from the Carboniferous Formation. Trans. Roy. Soc. Edinb., vol. xxxiii, p. I 50 .

: On the Fructification of Neuropteris heterophylla. Phil. Trans. Roy. Soc. London, ser. B, vol. cxcvii, I904.

: On the Microsporangia of the Pteridosperms. Proc. Roy. Soc., ser. B, vol. lxxvii, Jan. 6, 1906.

: Prel. Note on Microsporangia in organic connection with foliage of Lyginodendron (=Crossotheca Hoeninghausii). Proc. Roy. Soc., ser. B, vol. 1xxvi, p. 58, 1906.

Kraus : Ueber den Bau der Cycadeenfiedern. Pringsh. Jahrb., vol. iv, 1865-6.

LANG: Studies in the Development and Morphology of Cycadean Sporangia. I. The Microsporangia of Stangeria paradoxa. Ann. Bot., vol. xiv, 1897.

: Id. II. The Ovule of Stangeria paradoxa. Ann. Bot., vol. xiv, I900.

Lestibondois : Mémoire sur la structure des Cycadées. Comptes rendus, I860.

LIFE: The tuber-like Rootlets of Cycas revoluta. Bot. Gaz., vol. xxxi, I90I.

Lignier: La nervation taenioptéridée des folioles de Cycas et le tissu de transfusion. Bull. Soc. Linn. de Normandie, sér. 4, vol. iii, I888-9.

: Observations sur la nervation de la feuille du Cycas siamensis. Id., vol. viii, I894.

: La nervation des Cycadées est dichotomique. Cong. Assoc. pour l'avanc. des Sc., Caen, I 894 .

: Structure et affinités du Bennettites Morierei. Mém. Soc. Linn. de Normandie, vol. xviii, 1894 .

: Étude anatomique du Cycadeoidea micromyela. Id., vol. xx, I90I.

Lindley and Hutton: Fossil Flora of Great Britain, I 830. 
Lomax, J.: Some New Features in relation to Lyginodendron Oldhamium. Ann. Bot., vol. xvi, Dec. 1902.

MAtTe: Le mériphyte chez les Cycadacées. Compt. rend., I903.

- Une anomalie de structure dans l'écaille ovulifère du Ceratozamia mexicana. Bull. Soc. Linn. de Normandie, sér. 5 , vol. vii, I903.

- Recherches sur l'appareil libéro-ligneux des Cycadacées. Caen, 1904.

MetTenius : Beiträge zur Anatomie der Cycadeen. Abhandl. d. k. sächs. Ges. d. Wiss., vol. vii, $186 \mathrm{I}$.

MrQuel : Note sur l'Encephalartos horridus et sur ses différentes formes. Ann. d. Sci. Nat., sér. 3, Bot., vol. $x, 1883$.

: Note sur la préfoliation des Cycadées. Bull. d. Soc. Phys. de Néerlande, sér. 2, vol. xi, 1839 .

: Monographia Cycadearum. 1842.

: Ueber den Bau eines erwachsenen Stammes von Cycas circinalis. Linnaea, vol, xviii, 1844 .

MoHL, H. von : Ueber den Bau des Cycadeenstammes und sein Verhältniss zu dem Stamme der Coniferen und Baumfarne. Abhandl. d. k. bay. Ak. zu Münch., vol. i, I832, und Verm. Schriften, 1845 .

MOoRE : Einige Bemerkungen über die Gattung Macrozamia. Uebersetzt von Herm. Hienbaum. Wittmack's Gartenzeitung, vol. iii, No. 48 .

Nathorst: Beiträge z. Kenntniss einiger mesozoischen Cycadophyten. Kongl. Svenska Vetensk. Akad. Handl., Bd. xxxvi, No. 4, 1902.

Nestler : Beiträge zur Anatomie der Cycadeenfiedern. Pringsh. Jahrb., vol. xxvii, 1895.

Oliver, F. W.: The Ovules of the Older Gymnosperms. Ann. Bot., vol. xvii, I903.

: On the Structure and Affinities of Stephanospermum, Brongn., \&c. Trans. Linn. Soc., vol. vi, 1904 .

: Notes on Trigonocarpus, Brongn. and Polylophospermum, Brongn., two genera of Palaeozoic Seeds. New Phytologist, vol. iii, 1904.

Oliver And Scutt : On the Structure of the Palaeozoic Seed Lagenostoma Lomaxi. Phil. Trans. Roy. Soc. London, ser. B, vol. cxcvii, 1904.

Pearson, H. H. W. : Anatomy of the Seedling of Bowenia spectabilis. Ann. Bot., vol. xii, r898,

Potonié: Aus der Anatomie lebender Pteridophyten und von Cycas revoluia. Berlin, i887.

- : Lehrbuch der Pflanzenpalaeontologie. 1897.

Reinke : Beiträge zur Kenntniss der Gymnospermenwurzel. Morphol. Abhandl., Leipzig, I873.

RENAUlt: Cours de botanique fossile. Vol. I, I88I.

: Étude du genre Myelopteris. Mém. de l'Acad. d. Sc., vol. xxii, no. Io, I875.

: Tiges de la flore carbonifère. 1879.

: Bassin houiller et permien d'Autun et d'Épinac. Paris, 1896.

RichaRd, L. C. : Commentatio Botanica de Coniferis et Cycadeis. Stuttgart, 1826.

Richardson, T. G. : Dioon spinulosum. Gard. Chron., vol. xx, no. 254.

SAPORTA, G. DE : Paléontologie française. Végét. Pl. Jurass., $2^{\mathrm{e}}$ sér., vol. ii, I 875.

: Notice sur l'Encephalartos Gorceixianus, Cycadée fossile du dépot miocène de Koumi (Eubée). Bull. Soc. Bot. et Hort. de Provence, 1880.

Seward, A. C. : Notes on the Binney Collection of Coal-measure Plants. Part ii : Megaloxylon.

Proc. Camb. Phil. Soc., vol. x, 1899 . 1897.

: Fossil Plants of the Wealden. Part ii : Gymnospermae. Brit. Mus. Cat., I895.

: On Cycadeoidea gigantea, a new Cycadean Stem from the Purbeck Beds of Portland.

Quart. Journ. Geol. Soc., vol. liii, 1897.

: On the Leaves of Bennetitites. Proc. Camb. Phil. Soc., vol. ix, I897.

Seward And Gowan : The Maidenhair Tree (Ginkgo biloba, L.). Ann. Bot., vol. xiv, 1900.

ScotT, D. H. : The Anatomical characters presented by the Peduncle of the Cycadaceae. Ann.

Bot., vol. xi, 1897 .

: On Medullosa anglica, a new Representative of the Cycadofilices. Phil. Trans. Roy.

Soc. London, ser. B, vol. cxci, 1899.

: Studies in Fossil Botany. London, 1900. 


\section{58 Worsdell. - The Structure and Origin of the Cycadaceae.}

ScotT, D. H.: The Early History of Seed-bearing Plants as recorded in the Carboniferous Flora.

Wilde Lecture, Mem. and Proc. Manchester Lit. and Phil. Soc., I 905.

Scott and Maslen: On the Structure of Trigonocarfon olivaeforme. Ann. Bot., vol. xx, rgc6.

Solms-Laubach : Die Sprossfolge der Stangeria und der übrigen Cycadeen. Bot. Zeit., I89o.

: On Bennettites Gibsonianus. Ann. Bot., vol. v, I891.

: Fossil Botany. Eng. Ed., 189r.

: Pflanzenreste des Unterculm von Saalfeld. Abhandl. d. k. preuss. geol. Landes-

anstalt, neve Folge, Heft 23 , I896.

: Ueber Medullosa Leuckarti. Bot. Zeit., 1897 .

Stopes, M. C.: Beiträge zur Kenntniss der Fortpflanzungsorgane der Cycadeen. Flora, Bd. xciii, Heft 4,1904 .

: On the Double Nature of the Cycadean Integument. Ann. Bot., vol. xix, Oct. 1905.

STUR : Zur Morphologie und Systematik der Culın- und Carbonfarne. K. Akad. Wiss. Wien, I 883 .

Thiвout : Recherches sur l'appareil mâle des Gymnospermes. Lille, 1896 .

Thiselton-Dyer, W. T.: Cycas Micholitzii. Gardeners' Chronicle, Aug. 19, I905.

Tieghem, van : Anatomie de la fleur des Gymnospermes. Ann. d. Sci. Nat., sér. 5, vol. x, i 868.

TREUB : Recherches sur les Cycar'ées. Ann. d. Sci. Nat., sér. 6, vol. xii, i882 ; and Ann. Jard. Bot. Buitenz., vol. ii, I 882 , and iv, 1884 .

Vetters : Die Blattstiele der Cycadeen. Leipzig, i 884.

WARMing: Unders $\varnothing$ gelser og Betragninger over Cycadeerne. Oversigter over d K. D. Vidensk. Selsk. Forhandl., Copenhagen, 1877 .

: Fidrag til Cycadeernes Naturhistorie. Id., I879.

Webber : Researches upon Zamia. Bot. Gaz., vol. xxiv, 1897 .

Weber an d Sterzel: Beiträge zur Kenntniss der Medulloseae. Naturwiss. Ges. zu Chemnitz, xiii, 1896.

White, D.: The Seeds of Aneimites. Smithsonian Misc. Coll., vol. lxxiv, pt. 3, I904.

Wieland : A Study of some American Fossil Cycads. Part i: The Male Flower of Cy'cadeoidea. Amer. Journ. of Science, vol. vii, March, 1899.

: Id. Part ii : the Leaf-structure of Cycadeoidea. April, 1899.

: Id. Part iii : the Female Fructification of Cycadeoidea. May, 1899.

Wild, G.: On Trigonocarpon olivaeforme. Manchester Geol. Soc. Trans., vol. xxvi, 1900.

Williamson: On the Structure and Affinities of some Exogenous Stems from the Coal-Measures. Monthly Microscop. Journ., vol. ii, p. 66, 1869.

: Contributions towards the History of Zamia gigas. Trans. Linn. Soc., vol. xxvi, 1870.

: On the Organisation of the Fossil Plants of the Coal-Measures. Part iv : Dictyoxylon, Lyginodendron, and Heterangium. Phil. Trans. Roy. Soc., 1873.

: Id. Part vi : Ferns. Phil. Trans., vol. clxiv, 1874.

: Id. Part vii : Myelopteris, Psaronius, and Kalorylon. Phil. Trans., vol. clxvi, 1876 .

: Id. Part xvii : Lyginodendron, Oldhamium, and Rachiopteris astera. Phil. Trans., vol. clxxxi, I89o.

- And ScotT: Further Observations on the Organization of Fossil Plants of CoalMeasures. Part iii : Lyginodendron and Heterangium. Phil. Trans., vol. clxxxvi, 1895.

Worsdell: The Anatomy of the Stem of Macrozamia compared with that of other genera of Cycadeae. Ann. Bot., vol. x, 1896.

: On Transfusion-tissue : its origin and function in the leaves of Gymnospermous Plants. Trans. Linn. Soc., vol. v, I 897 .

: The Vascular Structure of the Sporophylls of the Cycadaceae. Ann. Bot., vol. xi, I 898.

: The Comparative Anatomy of certain genera of the Cycadaceae. Journ. Linn. Soc., vol. xxxiii, 1898 .

: The Structure of the Female 'Flower, in Coniferae; an historical study. Ann. Bot., vol. xiv, 1900 .

: The Comparative Anatomy of "icertain Species of Encephalartos. Trans. Linn. Soc., vol. v, 1900. 


\section{Wor:dell. - The Struture and Origin of the Cycadaceae. I59}

Worsdell : The Affinities of the Mesozoic Fossil Bennettites Gibsonianus. Ann. Bot., vol. xiv, I900.

: Contributions to the Comparative Anatomy of the Cycadaceae. Trans. Linn. Soc., vol. vi, r9or.

: The Origin of Modern Cycads. Rep. Brit. Assoc. Bradford, I 900.

: The Evolution of the Vascular Tissue of Plants. Pot. Gaz., vol. xxxiv, I902.

: The Morphology of Sporangial Integuments. Rep. Brit. Assoc. Belfast, I902.

-: The Structure and Morphology of the 'Ovule'; an historical sketch. Ann. Bot., vol. xviii, 1904 .

Zeiller : Flore fossile du bassin houiller de Valenciennes. I 888.

: Bassin houiller et permien d'Autun et d'Épinac. Vol. i, 1890.

: Une nouvelle classe de Gymnospermes: les Ptéridospermées. Revue gén. d. Sciences, Aug. 30, 1905 .

Zimmerman : Ueber das Transfusionsgewebe. Flora, I850. 


\section{$2 \mathrm{BHL}$ Biodiversity Heritage Library}

Worsdell, Wilson Crosfield. 1906. "The structure and origin of the Cycadaceae." Annals of botany 20, 129-159.

https://doi.org/10.1093/oxfordjournals.aob.a089088.

View This Item Online: https://www.biodiversitylibrary.org/item/234848

DOI: https://doi.org/10.1093/oxfordjournals.aob.a089088

Permalink: https://www.biodiversitylibrary.org/partpdf/318828

\section{Holding Institution}

Smithsonian Libraries

\section{Sponsored by}

Biodiversity Heritage Library

\section{Copyright \& Reuse}

Copyright Status: Not in copyright. The BHL knows of no copyright restrictions on this item.

This document was created from content at the Biodiversity Heritage Library, the world's largest open access digital library for biodiversity literature and archives. Visit BHL at https://www.biodiversitylibrary.org. 